\title{
ANALÝZA MOTIVAČNÝCH PREFERENCIÍ ZAMESTNANCOV VO VYBRANOM PODNIKU
}

\section{Henrieta Šuteková}

\section{Kl’účové slová:}

l'udské zdroje, motivačné preferencie, motivačná štruktúra, podnik, pracovná motivácia, výskum

\section{Key words:}

human resource, motivational preferences, motivational structure, company, work motivation, research

\begin{abstract}
Abstrakt
Príspevok je koncipovaný ako teoreticko - praktická štúdia pracovnej motivácie vo všeobecnosti a s konkrétnou aplikáciou na podmienky skúmaného podniku. Príspevok je doplnený o výsledky z prieskumu motivačnej štruktúry a motivačných preferencií zamestnancov skúmaného podniku, ktorý autorka realizovala. Základným ciel’om výskumu bolo zistit' a stanovit' faktory pracovnej motivácie, ich hierarchickú štruktúru determinovanú objektívnymi spoločensko-ekonomickými príčinami a určit' motivačné preferencie zamestnancov vybraného podniku. Pre tieto účely bola použitá dotazníková metóda. Z výsledkov výskumu vyplýva nasledovné poradie motivačných preferencií: faktory mzda, príležitost' k pracovnému postupu a náklonnost' nadriadeného sa umiestňujú na popredných miestach v motivačnej preferencii zamestnancov. Všetky ostatné motivačné faktory, ako stabilita zamestnania a dížka pracovnej doby, sú oproti nim menej významné.
\end{abstract}

\begin{abstract}
The contribution is outlined as a theoretical and practical study of working motovation in general, and with a specific application to the conditions of an enterprise under examination. The contribution is supplemented with results of survey carried out by the author focused on motivation structure and motivation preferences of the enterprise's employees. The primary objective of the research was to identify and determine the factors of working motivation, their hierarchical structure, determined by objective socio-economic causes, and to identify the motivational preferences of employees of a selected company. For this purpose, the method of questionnaire was used. The research results show the following order of motivational preferences: factors of salary, opportunity of promotion and superior person's affection have ranked high on the scale of staff motivational preferences. All other motivational factors such as stability of employment and working hours, are minor compared to them.
\end{abstract}

\section{Úvod}

Teoretické poznatky z oblasti pracovnej motivácie vytvárajú obraz o motivácii človeka v pracovnom procese, o možnostiach jeho stimulovania na podávanie vyšších výkonov a o možnostiach zefektívnenia a skvalitnenia jeho pracovnej činnosti, aby bol v zamestnaní nielen spokojný, ale aby bol aj prínosom pre zamestnávatel'a. Množstvo publikácií venovaných otázkam pracovnej motivácie vyvoláva záujem o riešenie a podporenie tejto problematiky v praktickej rovine, tzn. realizovanie výskumov, ktoré by overili platnost' teoretických záverov. Vo svete sa vykonáva mnoho sociologických výskumov zaoberajúcich sa 
analyzovaním pracovnej motivácie. Pre zaujímavost' možno uviest' jeden, ktorý realizoval Herzbergov kolektív vo Vel'kej Británii a jeho závery sú uplatnitel'né aj na špecifické pomery na Slovensku v súčasnosti. Jeho výsledky budú východiskom pri stanovovaní hypotéz pre potreby výskumu a pri formulácii otázok do dotazníka. Herzberg odhalil takéto poradie faktorov pracovnej motivácie: (Prigl, 1997)

- Bezpečnost', resp. istota, že človek môže pokračovat' v práci v tom istom podniku, alebo v takej istej profesii (uspokojenie jeho existenčných, psychologických a ekonomicko sociálnych potrieb).

- Príležitost' na postup, alebo záruka zlepšenia ekonomickej situácie, organizačného statusu alebo profesionálnej kvalifikácie.

- Prestíz podniku a kvalita jeho vedenia, čo súvisí s viacerými aspektmi sociálnej a personálnej politiky, so vzt’ahmi nadriadených a podriadených $\mathrm{v}$ podniku. Nedostatok dôvery má: „,negatívny vplyv na kultúru jednania a môže viest’ k sebeckým praktikám a slabej komunikácii na všetkých úrovniach.“ (Katuščáková, 2010)

- Mzda ako vel'mi výrazný a homogénny faktor, ktorý na seba viaže pocity spravodlivosti, hodnotenia, porovnávania sa, závislosti.

- Charakter práce. To znamená, vnútorný aspekt pracovnej činnosti, ktorý je závislý na pracovisku. Ide o pestrost', tvorivost', samostatnost', možnost' iniciatívy, sebauplatnenia a zodpovednost' v práci.

- Bezprostredný nadriadený a jeho vzt'ah k l'ud'om, spôsob komunikácie a konania, tolerancia, lojalita v prístupe, spravodlivost', pochopenie prekážok a t’ažkostí v práci.

- Sociálne hl'adiská pracovnej činnosti, akými sú: vzájomné vzt’ahy medzi l’ud’mi v práci, mimopracovné styky, spolupráca, priatel'stvo a pod.

- Komunikácia a tok informácií vo vnútri podniku, tak v pracovných, ako aj osobných veciach.

- Pracovné podmienky, začínajúc pracovnou dobou a končiac fyzikálnymi a estetickými aspektmi pracovného prostredia (čistota, osvetlenie, hluk, teplota, bezpečnost' pri práci, hygienické zariadenia).

- Pôžitky ako sú dovolenky, výhody dôchodkového či nemocenského zabezpečenia a d'alšie. Napríklad aj možnost' osobného rozvoja. „Rýchly rozvoj poznania, ktorý je dôsledkom nových technológií, vedie k potrebe celoživotného vzdelávania, ktoré musí byt' dostupné komukol'vek, kedykol'vek a kdekol'vek“" (Jakubíková, Kyselová, 2006).

Podobný výskum bol realizovaný v USA na vzorke tisíc respondentov, ktorých úlohou bolo zostavit' poradie desiatich faktorov týkajúcich sa práce. Jeho výsledky potvrdili, že očakávanie a preferencie $\mathrm{v}$ práci vel'mi silne ovplyvňuje pohlavie, vek, úroveň príjmu a organizačná úroveň, na ktorú je zamestnanec zaradený. 
Tabul'ka č. 1: Preferencie zamestnancov, poradie podl'a skupín (Donnelly, Gibson, Ivancevich, 2004)

\begin{tabular}{|c|c|c|c|c|c|c|c|c|c|c|c|}
\hline & \multicolumn{10}{|c|}{10 faktorov motivačných preferencií a ich poradie } \\
\hline & & 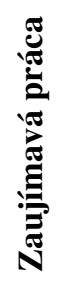 & 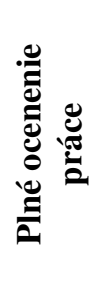 & 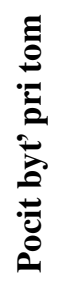 & & 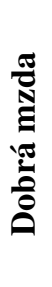 & 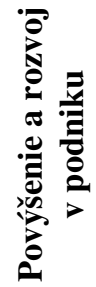 & 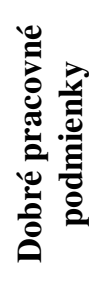 & 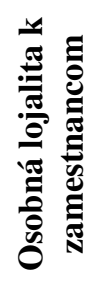 & 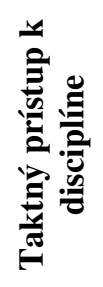 & 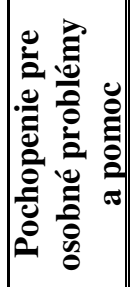 \\
\hline \multirow{2}{*}{$\frac{\sqrt{3}}{\frac{3}{0}}$} & muži & 2 & 1 & 3 & 5 & 4 & 6 & 7 & 8 & 9 & 10 \\
\hline & ženy & 2 & 1 & 3 & 4 & 5 & 6 & 7 & 8 & 9 & 10 \\
\hline \multirow{4}{*}{$\frac{\pi}{\partial}$} & do 30 rokov & 4 & 5 & 6 & 2 & 1 & 3 & 7 & 9 & 8 & 10 \\
\hline & $30-41$ & 2 & 3 & 4 & 1 & 5 & 6 & 7 & 9 & 10 & 8 \\
\hline & $42-50$ & 3 & 2 & 1 & 4 & 5 & 8 & 7 & 6 & 9 & 10 \\
\hline & 51 a viac & 1 & 2 & 3 & 7 & 8 & 9 & 4 & 5 & 10 & 6 \\
\hline \multirow{5}{*}{ 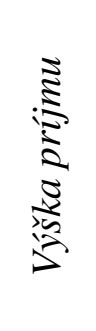 } & do 12000 & & & & & & & & & & \\
\hline & $12001-$ & 5 & 4 & 6 & 2 & 1 & 3 & 8 & 7 & 10 & 9 \\
\hline & $\begin{array}{c}18000 \\
18001-\end{array}$ & 2 & 3 & 1 & 4 & 5 & 6 & 7 & 8 & 9 & 10 \\
\hline & $\begin{array}{c}18001- \\
25000\end{array}$ & 1 & 3 & 2 & 4 & 6 & 5 & 7 & 8 & 9 & 10 \\
\hline & $\begin{array}{l}\text { viac ako } \\
25000\end{array}$ & 1 & 2 & 4 & 3 & 8 & 7 & 6 & 5 & 10 & 9 \\
\hline \multirow{2}{*}{ 닐 } & manuálna & 1 & 6 & 2 & 3 & 4 & 5 & 7 & 9 & 10 & 8 \\
\hline & nemanuálna & 2 & 1 & 4 & 5 & 6 & 3 & 7 & 8 & 9 & 10 \\
\hline
\end{tabular}

\section{Opis výskumu}

Z dôvodu získania prehl'adu o skutočnej situácii a o praktických možnostiach riešenia problematiky pracovnej motivácie bol realizovaný autorkou tohto príspevku sociologický výskum. Pre tieto účely existuje niekol'ko druhov výskumných metód. Z hl'adiska relevantnosti a verifikácie údajov bola zvolená metóda dotazníka. Dotazníková technika bola vhodná hlavne preto, že je pomerne jednoduchá a umožňuje zhromaždit' vel'ké množstvo údajov, ktoré je možné l'ahko kvantifikovat'. Medzi nevýhody použitia dotazníkovej techniky patria problémy s overitel'nost'ou platnosti a správnosti údajov uvedených respondentom. Taktiež neexistuje možnost' dotazníky v priebehu výskumu menit', tzn. nie je možné pružne reagovat' na rôzne zmenené situácie.

Realizácia sociologického výskumu bola rozdelená do troch základných etáp. V rámci prípravnej fázy bolo nevyhnutné uskutočnit' analýzu výskumného problému na základe preštudovania teoretických poznatkov z odbornej literatúry, formulovat' hlavný ciel' výskumu, stanovit' hypotézy, vymedzit' objekt a predmet výskumu, stanovit' výskumnú vzorku, rozvrhnút' časový harmonogram výskumu a stanovit' nástroje pre získanie empirického materiálu. V realizačnej fáze výskumu sa uskutočnila distribúcia a následný zber vyplnených dotazníkov. V etape spracovania výsledkov a ich implementácie sa využili metódy kvantitatívnej analýzy (vyjadrenie získaných hodnôt prostredníctvom základných 
matematicko - štatistických metód) a kvalitatívnej analýzy (prostredníctvom logických postupov stanovenie záverov výskumu).

Základnou a nosnou ideou výskumu bolo zistit' a stanovit' faktory pracovnej motivácie, ich hierarchickú štruktúru determinovanú objektívnymi spoločensko-ekonomickými príčinami a určit' motivačné preferencie zamestnancov vybraného podniku.

Výskumný dotazník, ktorý sa použil, bol štruktúrovaný do pätnástich otázok. Pre uskutočnenie zámerov a ciel'ov výskumu, bol konštruovaný na základe týchto kritérií a postulátov:

- rešpektovat' intelektuálnu, inteligenčnú a kultúrnu úroveň a zároveň psychológiu rôznych typov zamestnancov,

- položky dotazníka konštituovat' tak, aby vylučovali možnosti nesprávnych interpretácií jednoznačnou a zrozumitel'nou formuláciou,

- formu škálovania uspôsobit' tak, aby bola použitel'ná pri druhostupňovom a tret'ostupňovom triedení údajov,

- preferovat' uzavretý typ otázok a preferovat' projekčné otázky pred priamymi všade tam, kde to bude možné a vhodné,

- citlivo formulovat' otázky týkajúce sa vzt’ahu a spokojnosti s nadriadeným a spokojnosti so mzdou,

- plne zachovat' anonymitu respondentov na zvýšenie validity výsledkov.

Výskumný dotazník sa skladal z dvoch základných častí. Prvá čast' dotazníka (prvá otázka) bola konštituovaná na princípe dotazníka Bluma a Rusea. Zistovala hladinu významnosti a hierarchie pracovnej motivácie a motivačných postojov. Úlohou respondenta bolo zvolit' v každej otázke jednu odpoved', ktorá má preňho väčší význam a vyjadruje jeho osobné presvedčenie. Podstatou je výber z kombinácie piatich motivačných faktorov, ktoré majú rozhodujúcu úlohu v pracovnej motivácii. Uvažovalo sa o týchto faktoroch:

- mzda v kombinácii so stabilitou zamestnania, s pracovným postupom, s nadriadeným, s pracovnou dobou,

- nadriadený $\mathrm{v}$ kombinácii $\mathrm{s}$ pracovnou dobou, s pracovným postupom, so stabilitou zamestnania a so mzdou,

- stabilita zamestnania $\mathrm{v}$ kombinácii so mzdou, s pracovnou dobou, s pracovným postupom a s nadriadeným,

- pracovný postup v kombinácii s nadriadeným, so mzdou, so stabilitou zamestnania a s pracovnou dobou,

- pracovná doba $\mathrm{v}$ kombinácii so stabilitou zamestnania, s nadriadeným, so mzdou a $\mathrm{s}$ pracovným postupom.

Druhá čast' dotazníka zist'ovala prioritu jednotlivých motivačných faktoroch u každého respondenta a skúmala racionálny a emotívny aspekt motivácie zamestnancov vo vzt’ahu k vykonávanej práci.

Zo sociodemografických znakov, uvedených na začiatku dotazníka, sme skúmali pohlavie, vek, vzdelanie, dížka zamestnania v podniku, stav a pozícia, resp. pracovné zaradenie. Do dotazníka boli zakomponované preto, aby bolo možné v druhostupňovom triedení údajov kvalitatívne hlbšie posúdit' a analyzovat' získané výsledky a bližšie špecifikovat' jednotlivé skupiny respondentov.

Ked’že jedným z ciel'ov výskumu bolo analyzovat' motivačnú štruktúru a motivačné preferencie zamestnancov vo vybranom podniku, boli na spoluprácu oslovené viaceré podniky. Firmy však nie sú ochotné zadávat' objednávku výskumného spracovania 
problematiky pracovnej motivácie a ani neprejavujú záujem participovat' na tomto výskume. Dôvodom môže byt' tak nedôvera zo strany podniku voči vedeckým zamestnancom alebo študentom, ako aj obava zo zverejnenia výhradne vnútropodnikových informácií. Manažment, odmietnutie z uvedených dôvodov zakrýva za nedostatok času venovat' sa organizačnému zabezpečeniu výskumu, nevhodnosti načasovania alebo ako dôvod uvádza „,vyrušovanie zamestnancovej pozornosti na pracovnú činnost'“. Avšak spomenuté dôvody nie sú už prekážkou v prípade, ked' si podnik zaplatí za služby podobného charakteru realizované profesionálnymi spoločnost’ami. Nakoniec spomedzi oslovených firiem bola ochotná spolupracovat' len jedna. A nielen formálne (len v zmysle umožnenia distribúcie dotazníkov), ale jej riaditel' mal o výsledky zrealizovaného výskumu skutočný záujem.

Firma EMTEST, a.s. vznikla v roku 1990 a zamestnáva viac ako 200 zamestnancov. Do jej produktového portfólia patria najmä systémové riešenia pre verejnú dopravu, školstvo, knižnice, d’alej identifikačné (dochádzkové, stravovacie, parkovacie, prístupové systémy) a platobné systémy. Firma je členom medzinárodnej organizácie UITP sídliacej v Bruseli. Má zavedený certifikovaný systém riadenia kvality podl'a ISO 9001:2001.

Sociologický výskum sa realizoval v období september - október 2008. Výsledky výskumu predstavujú postoje a názory 202 respondentov pracujúcich v tomto podniku. Výskumná vzorka vykazovala nasledovnú štruktúru:

- pohlavie: $61 \%$ mužov a $39 \%$ žien,

- vek: $53 \%$ od 20 - 30 rokov, $34 \%$ od $30-40$ rokov, $13 \%$ od $40-50$ rokov, $0 \%$ od $50-60$ rokov (vzhl'adom k tomu, že len 2 respondenti uvádzali vek v rozpätí od 50-60 rokov, ich odpovede boli zahrnuté do odpovedí kategórie od 40-50 rokov),

- vzdelanie: $58 \%$ stredoškolské a $42 \%$ vysokoškolské,

- dÍžka zamestnania v podniku: $59 \%$ do 5 rokov, $41 \%$ od 5-10 rokov, $0 \%$ od 15-30 rokov, $0 \%$ nad 30 rokov (vzhl'adom $\mathrm{k}$ tomu, že len 1 respondent uvádzal dížku zamestnania v podniku od 15-30 rokov, jeho odpovede boli zahrnuté do odpovedí kategórie 5-10 rokov, prax nad 30 rokov neuvádzal ani jeden oslovený respondent),

- stav: $46 \%$ slobodný, $54 \%$ so záväzkami.

Výsledky mnohých výskumov naznačujú tendencie závislosti pracovnej motivácie od hodnôt a potrieb l'udí, ktoré súvisia s charakterom práce, stupňom ekonomického a technického rozvoja, hmotnou a kultúrnou úrovňou, pracovnými podmienkami a medzil'udskými vzt’ahmi v podniku. Poradie významnosti motivačných činitel'ov sa však mení v nadväznosti na zmeny potrieb človeka. Potreba, ktorá je uspokojená a v budúcnosti nebude ohrozená, stráca svoj motivačný význam. Zároveň sa preferencie motivačných faktorov dost' výrazne menia v závislosti od pohlavia, veku, vzdelania a d’alších znakov. Výskumy svedčia aj o tom, že motivácia k práci závisí od úrovne nezamestnanosti v danom období. V čase nezamestnanosti prevládajú motívy ekonomického charakteru: stabilita zamestnania, mzda, možnosti pracovného postupu. Motívy späté so vzt’ahmi medzi zamestnancami, medzi zamestnancami a vedením, sa považujú za najdôležitejšie počas relatívne vysokej zamestnanosti. Avšak s rastom nezamestnanosti sa motívy súvisiace so vzt’ahmi na pracovisku dostávajú až na posledné miesta (Kuzmin, Svencickij, 1985). Výskumy ukazujú vel'mi silnú závislost' medzi vekom respondenta a jeho vzt'ahom k práci. Pre mladých respondentov sú hlavnými faktormi spokojnosti s prácou možnosti funkčného postupu a charakter práce. Vekom vzrastá motivačný účinok zdravotno - hygienických podmienok práce, l'udia sa stávajú citlivejší na nepohodlie. Pre starších zamestnancov sa menej dôležitým stáva charakter vzt’ahu medzi zamestnancami a vedením, čo vyplýva $\mathrm{z}$ ich väčšej samostatnosti a ich vyššej prestíže v pracovnom kolektíve. Spokojnost's prácou má tendenciu s vekom narastat', avšak výskumy preukázali určitý pokles spokojnosti vo vekovej kategórii 
40 - 50 ročných (klesá spokojnost' s perspektívou povýšenia, ktorá však potom opät' rastie, pretože l'udia nad 50 rokov zrejme rezignovali a uspokojili sa s danou situáciou). Pracovné motívy mužov a žien sa podstatne odlišujú, čo zapríčiňujú tak psychofyziologické, ako aj sociálne faktory. Pre mužov sú dôležitejšie rozličné faktory súvisiace s obsahom a charakterom práce, rôznorodost', tvorivé možnosti, spoločenský význam. Ženy sú citlivejšie na pracovné podmienky, najmä na vzájomné vzt'ahy v kolektíve. Spokojnost' s prácou u žien, častejšie ako u mužov, ovplyvňuje výška zárobku.

Predpokladalo sa, že preferencie respondentov budú nasledovné: stabilita zamestnania, možnost' pracovného postupu, mzda, náklonnost' nadriadeného a dížka pracovnej doby. Vzhl'adom na súčasnú finančnú krízu a s tým súvisiacu nezamestnanost', sa očakávalo, že stabilita zamestnania bude najsilnejším faktorom v motivačnej preferencii zamestnancov. Jeho preferencia stúpa s vekom, hlavne u starších respondentov. Súvisí to s blízkost'ou dôchodkového veku a so zníženými adaptačnými schopnost’ami na zmenu práce. Naopak táto preferencia klesá u mladších respondentov, ktorí majú menšie problémy s nájdením nového zamestnania, sú adaptabilnejší a flexibilnejší na zmenené, nové, podmienky. Na druhé miesto bol zaradený motivačný faktor príležitost' na pracovný postup. Najmä z titulu toho, že môže u respondentov evokovat' predstavu vyššieho finančného ohodnotenia a pracovný postup je relatívne prirodzenou ambíciou takmer každého zamestnanca. Avšak sila tohto faktora sa výrazne mení s vekom. Mladšie vekové kategórie výraznejšie inklinujú k príležitosti na profesionálny rast. Je to zrejme dané tým, že pracovný postup u zamestnancov evokuje predstavu vyššieho finančného ohodnotenia, významnejšieho postavenia a výraznejšieho, nielen spoločenského uznania, ale aj uznania od kolegov a od nadriadených. Naopak staršie vekové kategórie už nemajú takéto ambície, ich osobnostné ašpirácie sú už zrejme saturované, sú ochotnejší akceptovat' úroveň, ktorú dosiahli. Dá sa predpokladat', že na tret'om mieste bude preferovaná mzda, vzhl'adom na relatívne nízky až priemerný životný štandard obyvatel'stva. Faktor príjemný nadriadený je síce značne motivačný, ale vzhl'adom na ostatné motivačné faktory, ktoré boli vyššie uvedené, sa javí ako menej významný, a preto je možné domnievat' sa, že bude v preferenciách zastávat' štvrtú pozíciu. Na posledné miesto bol zaradený motivačný faktor dížka pracovnej doby, ktorý zrejme nemá až takú motivačnú silu oproti už spomínaným štyrom faktorom.

Zároveň sa predpokladalo, že ak sú zamestnanci v zamestnaní spokojní, ani neuvažujú o jeho zmene. Avšak toto môže byt' determinované aj súčasnou finančnou krízou a mierou nezamestnanosti v spoločnosti. Taktiež sa vychádzalo z predpokladu, že spokojnost' s vykonávanou prácou je determinovaná nielen dostatočným finančným ohodnotením, ale aj tým, či zamestnancovi prináša radost', či sú naplnené jeho osobné ašpirácie v zmysle možností osobného rastu a pracovného postupu, aké sú medzil'udské vzt'ahy na pracovisku, či sú na výkon práce zabezpečené adekvátne pracovné podmienky. Zároveň sa pracovalo s domnienkou, že výrazným motivačným stimulom pri vykonávaní práce môže byt' uznanie od nadriadených, či kolegov. Predpokladalo sa, že zaujímavost' vykonávanej práce je vo výraznej miere ovplyvnená jej samotnou náplňou, prestížnost'ou podniku, výškou odmeny za jej vykonanie, poskytnutím priestoru na väčšiu právomoc a zodpovednost', na rozvíjanie schopností, na možnost' predkladat' vlastné návrhy a taktiež aj úrovňou pracovného prostredia a vybavenia. K dobrým výsledkom a vysokému výkonu môžu prispievat' pracovné podmienky, vzt'ahy v kolektíve a s nadriadeným, mzda podl'a výkonu, hodnotenie a spätná väzba od nadriadeného, vlastná sebamotivácia, stanovené vysoké ciele, dostatok informácií, možnost' neustáleho vzdelávania. Takisto možno predpokladat', že vel'mi demotivujúco môžu pôsobit' obavy zo straty zamestnania, kritika od nadriadeného, zlé vzt'ahy na pracovisku, či nemožnost' postupu, vysoké pracovné nasadenie, nevyhovujúce podmienky, nedostatočné uznanie, nízka mzda alebo monotónnost' práce. Najvýraznejšou obavou bude strata 
zamestnania. Ďalšie demotivujúce prvky budú viac-menej rovnocenné. Ich poradie bude závislé od preferencií jednotlivých skupín respondentov. Medzi dôvody odchodu zamestnancov z podniku môže patrit' nízka alebo nespravodlivá odmena, vysoká zát'až, nevyhovujúce pracovné prostredie a pracovná doba, zlé vzt’ahy v kolektíve, absencia uznania, malý priestor na postup a na d'alšie vzdelávanie, slabé sociálne a zamestnanecké výhody, zlé vzt'ahy s nadriadeným.

Vol'ba poradia dôležitosti z poskytnutých možností závisí od individuálnych osobných charakteristík respondentov, ako sú záujmy, potreby, postoje, city, zameranost', hodnotová orientácia, ideály a osobnostná štruktúra každého respondenta.

\section{Výsledky výskumu}

Ciel'om výskumu bolo overit' konkrétne teoretické skutočnosti týkajúce sa problematiky pracovnej motivácie zamestnancov skúmaného podniku. Bolo stanovených sedem hypotéz, ktorých potvrdenie alebo vyvrátenie sa uskutočnilo na základe získaných odpovedí od respondentov. Porovnanie výsledkov výskumu s hypotézami je nasledovné:

H1 Existuje predpoklad, že stabilita zamestnania bude v štruktúre motivačných preferencií najhomogénnejší a dominantný faktor. Na základe prvej otázky možno konštatovat', že vo všeobecnosti sa faktor stabilita zamestnania v štruktúre motivačných preferencií umiestnil až na predposlednom mieste. Respondenti viac preferovali mzdu, príležitost' k pracovnému postupu a náklonnost' nadriadeného. Je to zrejme spôsobené tým, že najväčšiu skupinu z respondentov (až 53\%) tvorili zamestnanci 20-30 roční a percentuálne bolo väčšie zastúpenie mužov (až 61\%). Tieto kategórie vnímajú stabilitu zamestnania v kontexte s inými faktormi menej citlivejšie ako napríklad ženy alebo ako staršie vekové kategórie. Na základe otázky č. 12 zároveň možno tvrdit', že strata zamestnania bola v poradí až druhým faktorom, hned' za nedostatočným finančným ohodnotením, ktorého sa respondenti najviac obávajú.

\section{Táto hypotéza sa nepotvrdila.}

H2 Existuje predpoklad, že faktor mzda bude mat’ pre mužov účinnejšiu motivačnú silu ako pre ženy a existuje predpoklad, že pre ženy bude atraktívnejší a homogénnejší faktor vzt'ah $k$ nadriadenému ako pre mužov. Na základe prvej otázky možno konštatovat', že pre mužov je faktor mzda motivačne účinnejší ako pre ženy. V rámci šiestej položky - vzt'ah mzda verzus náklonnost' nadriadeného - bolo jednoznačne preukázané, že ženy náklonnost' k nadriadenému (oproti vyššej mzde) preferujú viac ako muži. Avšak v rámci poradia dôležitosti faktorov ovplyvňujúcich záujem o prácu (otázka č.4), ženy výraznejšie preferovali finančné ohodnotenie (2. poradie) ako muži (3. poradie). Pri otázke č.5 boli odpovede respondentov ohl'adom daných faktorov rovnaké. Tak muži, ako aj ženy sa domnievajú, že k dobrým pracovným výsledkom prispieva najviac (1. poradie) finančné ohodnotenie (podl'a výkonu) a až na 5. mieste dobré vzt’ahy s nadriadeným. Taktiež v otázke preferovaných benefitov boli názory respondentov bez ohl'adu na pohlavie rovnaké. Najžiadanejším benefitom sú prémie, odmeny, vianočné príspevky a pod. Zároveň, tak ako pre ženy, tak aj pre mužov je nedostatočné finančné ohodnotenie najviac obávaným faktorom (otázka č. 12). Faktor, kritika nadriadeného a napätá komunikácia s ním, získal rovnaké poradie v preferenciách oslovených zamestnancov (rovnako mužov aj žien) ohl'adom najväčších obáv, resp. prekážok v zamestnaní. Aj v otázke č.14 boli postoje respondentov z hl'adiska pohlavia rovnaké, všetci by v prípade zmeny zamestnania zohl'adňovali lepšie finančné ohodnotenie. Uvedená hypotéza sa jednoznačne nepotvrdila.

H3 Existuje predpoklad, že tí respondenti, ktorí vnímajú prácu ako nezaujímavú, resp. zbytočnú, budú v práci nespokojní, resp. budú deklarovat', že podnik nesplnil ich očakávania. 
Na základe poslednej otázky, možno konštatovat', že respondenti, ktorí majú negatívny postoj k svojej práci, sú v $66 \%$ so svojou prácou nespokojní a domnievajú sa, že podnik, pre ktorý momentálne pracujú, nesplnil ich očakávania. Uvedená hypotéza sa potvrdila.

H4 Existuje predpoklad, že tí respondenti, pre ktorých je práca zaujímavá, budú deklarovat' postoj a vol'bu možnosti predkladat' vlastné návrhy a postupy medzi prioritné oblasti svojich preferencií. Tí respondenti, pre ktorých je práca zaujímavá, volili nasledovné poradie faktorov ovplyvňujúcich záujem o prácu: možnost' rozvíjat' svoje schopnosti a učit' sa nové, samotná náplň práce, finančné ohodnotenie, možnost' predkladat' vlastné návrhy a postupy, možnosti väčšej zodpovednosti pri plnení úloh, prestíž podniku, jeho úspešnost' na trhu, možnost' právomoci a samostatnej možnosti rozhodovat', adekvátne pracovné prostredie a vybavenie, možnost' pracovat' s l'ud'mi. Ked'že sa možnost' predkladat' vlastné návrhy nachádza v rámci preferencií na 4. mieste z 9, možno konštatovat', že uvedený faktor patrí medzi prioritné oblasti v rámci motivačnej hierarchie skupiny respondentov s daným postojom. Uvedená hypotéza sa potvrdila.

H5 Existuje predpoklad, že tí zamestnanci, ktorí budú deklarovat', že práca je pre nich zaujímavá pre samotný obsah práce (na prvom mieste), budú uvádzat', že sú so zamestnaním spokojní a nemenili by ho. Na základe analýzy odpovedí respondentov možno konštatovat', že uvedená hypotéza sa potvrdila, ked’že až $74 \%$ respondentov, ktorí deklarovali, že práca je pre nich zaujímavá pre samotný obsah práce (na prvom mieste), je so zamestnaním spokojných a nemenili by ho. Taktiež tí, ktorí deklarovali, že najvýznamnejším dôvodom zotrvávania v skúmanom podniku (otázka č.1) je zaujímavá práca, $57 \%$, sú so zamestnaním spokojní a nemenili by ho.

H6 Existuje predpoklad, že najväčšiu nespokojnost', resp. najväčšie obavy bude u respondentov vyvolávat' nedostatočné finančné ohodnotenie a strata zamestnania. Na základe otázky č. 12 možno skonštatovat', že pre väčšinu respondentov je nedostatočné finančné ohodnotenie a strata zamestnania (v tomto poradí) najväčšou obavou, resp. prekážkou v zamestnaní. Zároveň aj prostredníctvom otázky č.7 bolo zistené, že najväčšiu nespokojnost' zamestnanci pocit'ujú $\mathrm{k}$ výške mzdy. V rámci otázky č. 13 sa identifikovali podl'a názoru respondentov najčastejšie dôvody odchodu zamestnancov z podniku. Patrí k nim najmä zlé finančné ohodnotenie. Uvedená hypotéza sa potvrdila.

H7 Existuje predpoklad, že pri zmene zamestnania by respondenti volili možnost’ lepšieho finančného ohodnotenia alebo atraktívnejšie benefity na prvom mieste. Na základe otázky č. 14 možno tvrdit', že respondenti by pri zmene zamestnania zohl'adňovali lepšie finančné ohodnotenie, vyhovujúcejšie pracovné podmienky a lepšie sociálne a zamestnanecké výhody. V rámci otázky č. 13 sa identifikovali podl'a názoru respondentov najčastejšie dôvody odchodu zamestnancov z podniku. Patrí k nim najmä zlé finančné ohodnotenie. Uvedená hypotéza sa potvrdila.

Ciel'om výskumu bolo zistit' motivačnú štruktúru a preferencie zamestnancov, ako aj poznat' úroveň ich spokojnosti, resp. nespokojnosti. Na základe prvej otázky je možné vo všeobecnosti konštatovat', že faktory mzda, príležitost' k pracovnému postupu a náklonnost' nadriadeného sa umiestňujú na popredných miestach v motivačnej preferencii zamestnancov. Všetky ostatné motivačné faktory, ako stabilita zamestnania a dížka pracovnej doby, sú oproti nim menej významné. Ďalej je možné potvrdit' nasledovné skutočnosti:

- Mzda patrí stále k vyznávaným faktorom, ktoré stimulujú zamestnancov v práci, čo súvisí s ich existenčnými potrebami, ako aj so skutočnost’ou, že zamestnanci majú záujem v práci sa d’alej rozvíjat' (osobný rozvoj, rast) a záleží im na tom, akú pozíciu v zamestnaní vykonávajú. 
- Pracovné prostredie a medzil'udské vzt’ahy sú výrazne determinujúce faktory motivácie. Potvrdila sa skutočnost', že môžu v pozitívnom, aj v negatívnom zmysle vplývat' na celkovú pracovnú atmosféru, výkonnost' zamestnanca. Zo získaných výsledkov je možné konštatovat', že zamestnanci vel'mi citlivo vnímajú a reagujú na podmienky, v ktorých pracujú. Dobrá tímová spolupráca, komunikácia, štýl riadenia vplývajú na medzil'udské vzt'ahy, ktoré v konečnom dôsledku môžu pôsobit' silne motivačne alebo demotivačne.

- Potvrdila sa Teória $Y$, ktorá vychádza z toho, že l'udia majú záujem o prácu, vnímajú ju ako vel'mi zaujímavú, chcú sa d’alej rozvíjat' (je tu priestor aj pre sebamotiváciu, zamestnanci nechcú stagnovat'), čo je pozitívnym a cenným základom, na ktorom môže nielen skúmaný podnik stavat', pri vytváraní a udržiavaní motivujúceho prostredia a napĺn̆aní strategických ciel'ov.

- Najvýznamnejším faktorom ovplyvňujúcim záujem o prácu je samotná jej náplñ a možnost' rozvíjat' svoje schopnosti a učit' sa niečo nové. Ale faktory, možnost' neustáleho zvyšovania vedomostí, zručností a hodnotenie spolu so spätnou väzbou, sú podl'a respondentov najmenej významné determinanty dobrých pracovných výsledkov. Takýto výsledok môže byt' zrejme spôsobený aj tým, že respondenti prostredníctvom otázky č. 8 vyjadrili spokojnost's objektívnost'ou hodnotenia a informovania o kritériách hodnotenia len na úrovni hodnoty 2,54 (aritmetický priemer) a spätnú väzbu na zlepšenie výkonu na úrovni hodnoty 2,49. Možno v skúmanom podniku nie sú správne nastavené tieto mechanizmy a bolo by potrebné uskutočnit' systémovú zmenu.

- Podnik má záujem o svojich zamestnancov, zvolil pozitívnu motivačnú stratégiu, čo sa odrazilo na celkových výsledkoch a postojoch zamestnancov pri hodnotení spokojnosti k predloženým motivačným faktorom a k nadriadenému zvlášt'. Na základe výsledkov možno skonštatovat', že sú skôr spokojní ako nespokojní. Táto skutočnost' môže byt' pre skúmaný podnik mimoriadne povzbudzujúca, pretože spokojnost' zamestnancov patrí $\mathrm{k}$ najdôležitejším predpokladom na zvyšovanie efektívnosti ich pracovného výkonu a pre podnik na získanie konkurenčnej výhody.

- Nespokojnost' zamestnanci pocit'ovali najmä k výške mzdy, možnostiam kariérneho rastu a k zamestnaneckým výhodám. Vo vzt’ahu k svojmu nadriadenému menej kladne hodnotili najmä včasnost' a presnost' poskytovaných informácií, objektívnost' hodnotenia a informovanie o kritériách hodnotenia. Uvedené faktory by mal skúmaný podnik prehodnotit' a prijat' nápravné opatrenia na odstránenie tohto zdroja nespokojnosti.

- Väčšina zamestnancov vníma mzdu ako nižšiu oproti svojmu pracovnému nasadeniu. Kvôli vyššej mzde by boli v prvom rade ochotní zvyšovat' svoju odbornú kvalifikáciu a svedomitejšie a dôkladnejšie vykonávat' svoju prácu. Medzi benefity, ktoré by najviac uvítali patria zamestnanecké výhody finančného charakteru a možnost' d'alšieho vzdelávania.

- Zamestnanci sa najviac obávajú nedostatočného finančného ohodnotenia a straty zamestnania. Ale najmenej pocit'ujú strach z monotónnosti a stereotypu práce, nevyhovujúceho štýlu vedenia nadriadeného a zlých vzt’ahov a sporov na pracovisku. Tento výsledok je však pochopitel'ný, pretože v otázke č.7 s týmito faktormi vyjadrili spokojnost'.

- Najčastejším dôvodom fluktuácie sú zlé finančné ohodnotenie a nedostatočné ocenenie práce. V prípade zvažovania, či opustit' skúmaný podnik alebo zostat' nad'alej pracovat', by zamestnanci zohl'adňovali lepšie finančné ohodnotenie a vyhovujúcejšie pracovné podmienky.

Na záver možno skonštatovat', že pre väčšinu respondentov skúmaný podnik splnil ich očakávania, že sú v zamestnaní spokojní, odporučili by ho aj svojim známym a keby opätovne stáli pred rozhodnutím zamestnat' sa v uvedenom podniku, vybrali by si rovnako. 


\section{Záver}

I napriek dostatočným zdrojom odbornej literatúry a množstva výskumov chýba ucelená teória pracovnej motivácie, ktorá by zohl'adňovala závery všetkých existujúcich čiastkových výsledkov a súhrne, vyčerpávajúco riešila túto problematiku. Neexistuje univerzálne platný návod, ako by mali manažéri postupovat' pri vytváraní motivujúceho pracovného prostredia. Chýbajú metodické návody na tvorbu motivačných programov, na výber účinných motivačných prvkov, na riadenie procesu pracovnej motivácie. Z hl'adiska výskumného spracovania tejto problematiky sa vyskytuje problém so získaním validných informácií. $\mathrm{Na}$ základe obvykle zaužívaných postupov je možné získat' len sprostredkované a pomerne málo spol’ahlivé informácie.

\section{Literatúra:}

[1] BOROŠ, J.: Základy sociálnej psychológie. Bratislava: IRIS, 2001. 227 s. ISBN 808901-820-3

[2] DONNELLY, J. H. JR. - GIBSON, J. L. - IVANCEVICH, J. M.: Management. 1. vyd. Praha: Grada Publishing a.s., 2004. 821 s. ISBN 80-7169-422-3

[3] FUCHSOVÁ, K. - KRAVČ́AKOVÁ, G.: Manažment pracovnej motivácie. 1. vyd. Bratislava: IRIS, 2004. 170 s. ISBN 80-89018-66-1

[4] JAKUBÍKOVÁ, B. - PRIGLOVÁ, H. - PRIGL, A.: Motivation as realisation of needs and interests. In: Communications - Vol. 9, Scientific Letters of the University of Žilina, 2007. č. 2, s. 34 - 39, ISSN 1335-4205

[5] JAKUBÍKOVÁ, B. - KYSELOVÁ, D.: Informačné a komunikačné technológie a základné školstvo $v$ základných číslach jedného výskumu. In: Zborník abstraktov a elektronických verzií recenzovaných príspevkov na CD - ROMe. XXIV. medzinárodné kolokvium o riadení osvojovacieho procesu zamerané na aktuálne problémy vedy, výchovy, vzdelávania a rozvoja tvorivého myslenia. Brno: Univerzita obrany, Fakulta ekonomiky a managementu, 2006. ISBN 80-7231-139-5

[6] KATUŠČÁKOVÁ, M.: Učenie sa a učenie v znalostnej spoločnosti. In: XXV. International Colloquium on the Management of Educational Process aimed at current issues in science, education and crearive thinking development. Brno: Univerzita obrany - Fakulta ekonomiky a managementu, 2007. ISBN 978-80-7231-228-3

[7] KUZMIN, J. S. a kol.: Sociálna psychológia v podniku. 1vyd. Bratislava: ROH, 1985. $195 \mathrm{~s}$.

[8] PRIGL, A.: Vybrané kapitoly zo sociológie so zameraním na riadenie l’udských zdrojov. 1. vyd. Žilina: Žilinská univerzita v Žiline, EDIS, 1997. 138 s. ISBN 80-7100-402-2

[9] PROVAZNÍK, V. - KOMÁRKOVÁ, R.: Motivace pracovního jednání. 1. vyd. Praha: Vysoká škola ekonomická v Prahe, Oeconomica, 2004. 128 s. ISBN 80-245-0703-X

[10] RŮŽIČKA, J.: Motivace pracovního jednání. 1. vyd. Praha: Vysoká škola ekonomická v Prahe, 1992. 170 s. ISBN 80-7079-626-X

\section{JEL J 21, J 53, M 12}

\section{Ing. Henrieta Šuteková, PhD.}

Katedra mediamatiky a kultúrneho dedičstva

Fakulta humanitných vied

Žilinská univerzita v Žiline

Univerzitná 8215/1, Žilina, SR

henrieta.sutekova@fpv.uniza.sk 